\title{
Strategi Kepala Sekolah dalam Meningkatkan Kualitas Pembelajaran Melalui Pengembangan Sarana Prasarana
}

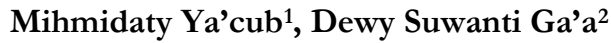 \\ ${ }^{1}$ Universitas Islam Negeri Sunan Ampel Surabaya, Indonesia \\ ${ }^{2}$ Sekolab Tinggi Ilmu Tarbiyah Al-Urwatul Wutsqo Jombang, Indonesia \\ e-mail: mihmidaty@gmail.com,dewysga@gmail.com
}

Submitted: 28-06-2021 Revised : 18-09-2021 Accepted: 25-09-2021

\begin{abstract}
The principal as a manager or leader must have a strategy in developing educational facilities and infrastructure. Educational facilities and infrastructure are one of important resources in supporting the learning process in schools. The purpose of this article is to describe the principal's strategy in improving infrastructure through the development of infrastructure. This article is qualitative field research. The form of the research is descriptive qualitative with the design of data collection techniques through observation, interviews, and documentation. Furthermore, data analysis was carried out using descriptive qualitative analysis. The results of this article found that the principal's strategy in improving the quality of learning through the development of infrastructure at (Public High School) SMA Negeri 1 Jombang was quite effective and efficient, especially seen from the presence of CCTV facilities that made it easier for the principal to control the teachers, as well as students during the learning process and LCD can understand the material presented by the teachers. The principal strategy in developing infrastructure is through the planning stages of infrastructure, organizing infrastructure, mobilizing infrastructure, and controlling infrastructure. The conclusion from the explanation above is that the principal's strategy in improving the quality of learning through the development of infrastructure at SMA Negeri 1 Jombang seen from the CCTV and LCD facilities is quite good because after seeing the results achieved, it has fulfilled the objectives to be achieved, namely to improve the quality of learning.
\end{abstract}

Keywords: Principal, Infrastructure, Quality of Learning,

https://doi.org/10.31538/munaddhomah.v2i2.67

How to Cite Ya`cub, M. Ga`a, D.S. (2021). Strategi Kepala Sekolah dalam Meningkatkan Kualitas Pembelajaran Melalui Pengembangan Sarana Prasarana. Munaddhomab: Jurnal Manajemen Pendidikan Islam, Volume 2 (2),

\section{PENDAHULUAN}

Keberhasilan suatu lembaga pendidikan sangat tergantung pada kepemimpinan kepala sekolah (Ariyanti et al., 2019; Liu \& Gumah, 2020; Lussier \& Achua, 2013). Karena kepala sekolah sebagai pemimpin di lembaganya, maka dia harus membawa lembaganya kearah tercapainya tujuan yang telah ditetapkan, dia harus mampu melihat adanya perubahan serta mampu melihat masa depan dalam kehidupan globalisasi yang lebih baik(Asmendri, 2014; Brooks \& Sungtong, 2016). Kepala sekolah harus bertanggung atas kelancaran dan keberhasilan semua urusan pengaturan dan pengelolaan secara formal kepada atasanya atau informal kepada masyarakat yang telah menitipkan anak didiknya (Fitrah, 2017). Menurut (Wahjosumidjo, 1999) Kepala sekolah adalah tenaga fungsional guru yang diberi tugas untuk memimpin suatu sekolah di mana diselenggarakan proses belajar mengajar atau tempat di mana terjadi interaksi antara guru yang memberi pelajaran dan murid yang menerima pelajaran. 
Berdasarkan hasil penelitian (Tanjong, 2017) didalam penelitiannya mengenai strategi kepala sekolah dalam peningkatan mutu pembelajaran di SMAN 1 Samalanga, ditemukan bahwa kepala sekolah dalam kontek penyelenggaraan pendidikan memiliki peran yang sangat strategis sebagai pemimpin. Oleh karena itu tanggung jawab sekolah dalam meningkatkan mutu pembelajarannya terletak di tangan kepala sekolah. Seorang kepala sekolah harus berkompeten dalam bidangnya dan bertanggung jawab terhadap tugas-tugasnya. Strategi yang dilakukan kepala sekolah dalam meningkatkan mutu pendidikan merupakan pihak yang terbuka sesuai dengan situasi dan kondisi sekolah yang dipimpinya (Fajriana \& Aliyah, 2019; Yuliana, 2018). Strategi yang diterapkan oleh kepala sekolah dalam meningkatkan mutu pembelajaran meliputi: peningkatan kemampuan mengajar guru, pendayagunaan media dan sarana pendidikan, pelaksanaan supervisi secara rutin, menjalin kerja sama dengan masyarakat dan penerapan disiplin waktu yang kerat, baik bagi guru mapun bagi siswa.

Menurut (Fauzi, 2017) bahwa Kepala sekolah sebagai seorang manajer atau pemimpin harus mempunyai strategi dalam mengembangkan sarana dan prasarana pendidikan. Kepala sekolah harus mempunyai kemampuan dasar dalam menyusun analisis kebutuhan dan perencanaan sarana dan prasarana pendidikan sehingga adanya kesesuaian antara kebutuhan sekolah dengan sarana dan prasarana yang ingin ditambahkan. Selain itu, peran kepala sekolah dalam mengikut sertakan guru dan siswa dalam perencanaan sarana dan prasarana pendidikan juga sangat dibutuhkan karena sarana dan prasarana ini nantinya yang akan menunjang aktivitas mereka selama berada di lingkungan sekolah (Muslimin \& Kartiko, 2020).

Strategi kepala sekolah dalam melibatkan baik secara langsung maupun tidak pihak guru dan siswanya akan mempengaruhi tingkat keberhasilan pengembangan sarana dan prasarana di suatu sekolah. Sarana dan prasarana pendidikan merupakan salah satu sumber daya yang penting dalam menunjang proses pembelajaran di sekolah (Fitriani \& Hakim, 2021). Keberhasilan program pendidikan di sekolah sangat dipengaruhi oleh kondisi sarana dan prasarana pendidikan yang dimiliki sekolah dan oleh optimalisasi pengelolaan dan pemanfaatannya. Menurut (Mulyasa, 2013) Pengelolaan terhadap sarana dan prasarana itu terbilang penting karena dengan adanya sarana dan prasarana yang memadai supaya bisa digunakan dengan benar dan dapat digunakan untuk menunjang kelancaran proses belajar mengajar, selain itu juga untuk menjaga ketahanan sarana dan prasarana pendidikan karena akan digunakan dalam jangka waktu yang tidak pendek sehingga harus dikelola dengan baik.

Pada realitanya sekolah masih mengalami beberapa kendala dalam mengembangkan sarana dan prasarana pendidikan. Kendala-kendala dalam pengembangan sarana dan prasarana antara lain: keterbatasan biaya, kelebihan sarana dan prasarana yang sebenarnya tidak 'urgent' dibutuhkan di sekolah, ketersediaan jumlah sarana dan prasarana pendidikan dalam menunjang pembelajaran tidak sebanding dengan jumlah siswa dan guru di sekolah tersebut sehingga sarana dan prasarana tersebut hanya tersimpan di dalam gudang dan lama kelamaan menjadi rusak sebelum digunakan untuk menunjang kegiatan pembelajaran di sekolah (Nilda et al., 2020). Masalah atau kendala ini dapat terjadi karena kurangnya kesadaran seluruh komponen yang ada di sekolah mengenai pentingnya pengembangan sarana dan prasarana pendidikan secara tepat, khususnya kepala sekolah. Pada kenyataannya, belum banyak kepala sekolah yang mampu mengelola sarana dan prasarana pendidikan secara tepat (Ma arif \& Rusydi, 2020).

Salah satu indikator sekolah bermutu atau tidak dapat dilihat dari kelengkapan sarana dan prasarana pendidikannya dalam menunjang proses pembelajaran di sekolah. Semakin baik dan lengkap sarana dan prasarana pendidikan yang terdapat di suatu sekolah maka persepsi masyarakat terhadap mutu sekolah tersebut juga akan semakin baik (Martin \& Fuad, 2016). Menurut (Ibrahim, 2008) Para pakar pendidikan sering kali menegaskan bahwa guru merupakan sumber daya manusia yang sangat menentukan keberhasilan program pendidikan. Namun, tidak berarti bahwa keberadaan unsur-unsur lainnya tidak begitu penting bagi 
peningkatan mutu pendidikan di sekolah. Dalam rangka meningkatkan mutu pendidikan khususnya pembelajaran di sekolah perlu adanya layanan yang profesional dibidang sarana dan prasarana bagi guru dan kepala sekolah sehingga memudahkan mereka dalam melaksanakan tugasnya secara efektif dan efisien. Menurut (Martin \& Fuad, 2016) Sarana dan prasarana pendidikan merupakan salah satu sumber daya yang penting dalam menunjang proses pembelajaran di sekolah. Keberhasilan program pendidikan di sekolah sangat dipengaruhi oleh kondisi sarana dan prasarana pendidikan yang dimiliki sekolah dan oleh optimalisasi pengelolaan dan pemanfaatannya.

Menurut (Amirudin, 2019) Pengelolaan terhadap sarana dan prasarana terbilang penting karena dengan adanya sarana dan prasarana yang memadai supaya bisa digunakan dengan benar dan dapat digunakan untuk menunjang kelancaran proses belajar mengajar, selain itu juga untuk menjaga ketahanan ataupun keawetan sarana dan prasarana pendidikan karena akan digunakan dalam jangka waktu yang tidak pendek sehingga harus dikelola dengan baik. Mutu proses pembelajaran ditentukan melalui metode, masukan, suasana, dan kemampuan melaksanakan manajemen proses pembelajaran itu sendiri. Mutu proses pembelajaran akan ditentukan dengan seberapa besar kemampuan memberdayakan sumber daya yang ada untuk peserta didik belajar secara produktif (Fatoni, 2017).

Penelitian ini dilaksanakan di SMAN 1 Jombang. Dalam pengembangan sarana prasarana perlu menjadi prioritas untuk dikaji, kaitannya dengan hal itu, setiap sekolah pasti memiliki sarana prasarana yang cukup memadai demi meningkatkan proses pembelajaran. Dalam meningkatkan kualitas pembelajaran kepala sekolah SMA Negeri 1 Jombang memiliki strategi yakni dengan menerapkan CCTV srta LCD disetiap sudut ruangan kelas.

\section{METODE PENELITIAN}

Peneliti menggunakan metode penelitian kualitatif, seperti yang dijelaskan oleh Sugiyono bahwa penelitian kualitatif adalah penelitian lapangan (field research) karena data yang dihasilkan berupa kata-kata tertulis atau lisan dari obyek dan perilaku yang dapat diamati (Lexy J, 2011; Sugiyono, 2014). Sedangkan desain dalam penelitian ini menggunakan, desain deskriptif kualitatif bertujuan untuk menggambarkan, meringkas berbagai kondisi, situasi, atau berbagai fenomena realitas sosial yang ada di masyarakat yang menjadi objek penelitian. Deskriptif kualitatif digunakan untuk meneliti masalah-masalah yang membutuhkan study mendalam mengenai suatu penelitian (Creswell, 2007). Teknik pengumpulan data yang digunakan peneliti adalah observasi, wawancara dan dokumentasi maka peneliti menggunakan lembar observasi, wawancara dan dokumentasi sebagai instrument. Informan dari penelitian ini adalah kepala sekolah, komite sekolah, beberapa guru sesuai rekomendasi kepala sekolah, staff dan wali murid. Tehnik analisis data menggunakan model (Miles et al., 2014) yaitu dengan, reduksi data, penyajian data dan panarikan kesimpulan.

\section{KAJIAN TEORI}

\section{Konsep Strategi Kepala Sekolah}

Keberhasilan pembelajaran di sekolah didukung dengan adanya pendayagunaan sarana prasarana pendidikan secara efektif dan efisien. Menurut (Sulistyorini, 2009) Sarana pendidikan adalah peralatan dan perlengkapan yang secara langsung dipergunakan untuk menunjang proses pendidikan, khususnya proses belajar mengajar seperti gedung, ruang, kelas, meja kursi, serta alat-alat dan media pengajaran. Adapun yang dimaksud dengan prasarana pendidikan adalah fasilitas yang secara tidak langsung menunjang jalannya proses pendidikan atau pengajaran, seperti halaman, kebun, taman sekolah, jalan menuju sekolah, tetapi jika dimanfaatkan secara langsung untuk proses belajar mengajar, seperti taman sekolah untuk pengajaran biologi, halaman sekolah sebagai sekaligus lapangan olah raga, komponen tersebut merupakan sarana pendidikan. 
Manajemen sarana dan prasarana pendidikan dapat didefinisikan sebagai proses kerja sama pendayagunaan semua sarana dan prasarana pendidikan secara efektif dan efisien. Definisi ini menunjukkan bahwa sarana dan prasarana yang ada disekolah perlu didayagunakan dan dikelola untuk kepentingan proses pembelajaran di sekolah. penting di sekolah, karena keberadaannya akan sangat mendukung terhadap suksesnya proses pembelajaran di sekolah.

Menurut (Barmawi \& Arifin, 2016) Sarana dan prasarana dalam lembaga pendidikan itu sebaiknya dikelola dengan sebaik mungkin dengan mengikuti kebutuhan-kebutuhan sebagai berikut: 1) Lengkap, siap dipakai setiap saat, kuat dan awet. 2) Rapi, indah, bersih, anggun, dan asri sehingga menyejukkan pandangan dan prasaan siapa pun yang memasuki kompleks lembaga pendidikan, 3) Kreatif, inovatif, responsif, dan bervariasi sehingga dapat merangsang timbulnya imajinasi peserta didik, 4) Memiliki jangkauan waktu yang panjang melalui perencanaan yang matang untuk menghindari kecendrungan bongkar pasang bangunan, 5) Memiliki tempat khusus untuk beribadah maupun pelaksanaan kegiatan sosio-religious, seperti mushola atau masjid.

Sarana dan prasarana itu harus dikelola supaya bisa membantu pembelajaran sehingga bisa dimanfaatkan secara maksimal dan dapat memenuhi kebutuhan dalam proses pendidikan, sehingga ketersediaan sarana dan prasarana itu tidak sia-sia, dan dengan adanya sarana dan prasarana pendidikan diharapkan pembelajaran akan memperoleh hasil yang sesuai dengan apa yang telah ditetapkan sebagai tujuan pembelajan.

Tujuan dari manajemen sarana prasarana adalah sebagai berikut: 1) Untuk mengupayakan pengadaan sarana dan prasaran pendidikan melalui system perencanaan dan pengadaan secara hati-hati dan saksama, sehingga sekolah atau madrasah memiliki sarana dan prasarana yang baik sesuai dengan kebutuhan dana yang efisien. 2) Untuk mengupayakan pemakaian sarana dan prasarana sekolah itu harus secara tepat dan efisien. 3) Untuk mengupayakan pemeliharaan sarana prasarana pendidikan secara teliti dan tepat, sehingga keberadaan sarana dan prasarana tersebut akan selalu dalam keadaan siap pakai ketika akan digunakan atau diterapkan. Jadi, tujuan dari sarana prasarana pendidikan yaitu agar dapat memberikan kontribusi yang optimal dan professional (yang berkaitan dengan sarana prasrana) terhadap proses pendidikan dalam mencapai tujuan pendidikan yang telah ditetapkan.

Menurut (Badriah et al., 2020) Strategi berkaitan erat dengan bagaimana melakukan sesuatu untuk mencapai tujuan tertentu. Strategi merupakan seni untuk mengelola sumber daya agar mampu mencapai sasaran yang dituju dengan efektif dan efisien. Menurut (Mulyasa, 2012) Strategi yang diterapkan kepala sekolah dalam mengembangkan sarana dan prasarana sekolah adalah:

\section{Kepala sekolah sebagai perencanaan sarana prasarana}

Pada hakiktnya, perencanaa adalah aktivitas pengambilan keputusan mengenai sasaran (objektives) apa yang akan dicapai, tindakan apa yang akan diambil dalam rangka pencapaian tujuan dan siapa yang akan melaksanakan tugas-tugasnya. Dimana perencanaan disini adalah proses penentuan tujuan atau sasaran yang hendak dicapai dan menetapkan jalan sumber yang diperlukan untuk mencapai tujuan itu seefisien dan seefektif mungkin.

Dari beberapa definisi di atas, dapat diambil sebuah pemahaman bahwa perencanaan pada lembaga pendidikan merupakan kegiatan sistematis merancang sumber daya lembaga, meliputi mengenai apa yang akan dicapai (diidealkan), kegiatan yang perlu dilakukan untuk mencapai tujuan dan memilih pelaksana kegiatan yang tepat bagi usaha pencapaian tujuan. Menurut (Danim, 2009) Perencanaan adalah proses pemikiran secara matang untuk menetapkan kegiatankegiatan yang akan dilakukan dimasa yang akan datang. Dalam pengembangan sarana prasarana perencanaan diarahkan terutama dalam rangka perencanaan kebutuhan perlengkapan sarana dan prasarana. Dalam menyusun rencaca kebutuhan, hendaknya diperhatikan keadaan inventaris pada tahun-tahun sebelumnya (penambahan dan penggantian) dan diperhitungkan juga pegawai yang ada (menurut informasi yang telah ada), disamping adanya kekhususan tugas yang ada. 
Menurut (Barnawi \& Arifin, 2016) Hasil suatu perencanaan akan menjadi pedoman dalam pelaksanaan dan pengendalian, oleh karena itu, perencanaan sarana prasarana harus dilakukan dengan baik dengan memperhatikan persyaratan dari perencanaan yang baik.

\section{Kepala sekolah sebagai pengorganisasian sarana prasarana}

Menurut Baharuddin, dalam (Khoiri, 2016) pengorganisasian sebagai keseluruhan proses pengelompokan orang-orang, alat-alat tugas, tanggung jawab atau wewenang sedemikian rupa, sehingga tercipta suatu organisasi yang dapat digerakkan sebagai satu kesatuan dalam rangka mencapai tujuan yang telah ditetapkan.

Dapat disimpulkan bahwasanya pengorganisasian merupakan langkah ke arah pelaksanaan rencana yang telah disusun sebelumnya. Jadi kegiatan pengorganisasian merupakan fungsi organik yang ketiga dalam manajemen. Adapun proses organizing, meliputi berbagai rangkaian kegiatan yang bermula pada orientasi atas tujuan yang direncanakan dan berakhir pada saat kerangka organisasi yang tercipta terlengkapi dengan prosedur dan metode kerja, kewenangan, personalia serta ketersediaan peralatan yang dibutuhkan.

\section{Kepala sekolah sebagai penggerak sarana prasarana}

Actuating sebagai tindakan untuk mengusahakan agar semua anggota kelompok suka berusaha untuk mencapai sasaran-sasaran, agar sesuai dengan perencanaan menejerial dan usahausaha organisasi. Penggerakan (actuating) adalah hubungan antara aspek- aspek individual yang ditimbulkan oleh adanya hubungan terhadap bawahan untuk dapat mengerti dan memahami pembagian pekerjaan yang efektif dan efisien. Actuating adalah bagian yang sangat penting dalam proses menejemen, berbeda dengan ketiga fungsi yang lain (planing, organizing, controlling, actualing).

\section{Kepala sekolah sebagai pemeliharaan sarana prasarana}

Pengawasan adalah proses penentuan apa yang dicapai, berkaitan dengan standar apa yang sedang dihasilkan, penilaian pelaksanaan (performance) serta bilamana perlu diambil tindakan korektif, ini yang memungkinkan pelaksanaan dapat berjalan sesuai rencana, yakni sesuai dengan standar yang diharapkan. Menurut (Sulistyorini, 2009) Pengawasan merupakan salah satu fungsi manajemen yang harus dilaksanakan oleh pimpinan organisasi. Berkaitan dengan sarana dan prasarana pendidikan di sekolah, perlu adanya kontrol baik dalam pemeliharaan atau pemberdayaan. Pengawasan (control) terhadap sarana dan prasaran pendidikan di sekolah merupakan usaha yang ditempuh oleh pimpinan dalam membantu personil sekolah dengan sebaik mungkin demi keberhasilan proses pembelajaran di sekolah.

Tujuan pengawasan dalam konsep sistem adalah membantu mempertahankan hasil atau out-put yang sesuai dengan syarat- syarat sistem. Artinya dengan melakukan kerja pengawasan, diharapkan dapat mencapai kualitas produk organisasi berdasarkan perencanaan yang telah ditetapkan, sehingga konsumen atau stakeholders menjadi puas. Agar kegatan pengawas berjalan efektif ketika melalui tiga tahapan yaitu: tahapan penetapan alat ukur, tahapan mengadakan penilaian, tahapan tindakan perbaikan. Menurut (Wahjosumidjo, 2007) Pada fase pertama, pemimpin arus menentukan alat-alat pengukur apa yang akan digunakan. Berdasarkan standar ini kemudian diadakan penilaian atau evaluasi, yakni membandingkan pekerjaan yang telah dikerjakan dengan standar yang telah ditetapkan. Jika terdapat ketidaksamaan dihasil akhir atau tidak sama dengan standar, maka dapat dilakukan tindakan perbaikan, agar pengawasan dapat terealisir dengan baik. Yang mana pengawasan seharusnya merupakan ceorcion atau compeling, artinya proses yang bersifat memaksa, agar kegiatan-kegiatan pelaksana dapat disesuaikan dengan rencana yang telah ditetapkan.

\section{Kualitas Pembelajaran}

Menurut Amri, dalam (Hamdi, 2019) Kualitas atau mutu dalam pendidikan bukanlah barang melainkan layanan, dimana mutu harus dapat memenuhi kebutuhan, harapan, dan keinginan semua pihak atau pemakai dengan focus utamanya terletak pada peserta didik. Mutu pendidikan berkembang seirama dengan tuntunan kebutuhan hasil pendidikan yang berkaitan dengan kemajuan ilmu dan teknologi yang melekat pada wujud pengembangan kualitas sumber daya manusia. 
Oemar Malik berpendapat bahwa pengertian mutu dapat dilihat dari dua sisi, yaitu segi normatif dan deksriptif. Dalam arti normatif, mutu ditentukan berdasarkan pertimbangan (kriteria) intrinsik dan ekstrinsik. Berdasarkan kriteria intrinsik, mutu pendidikan merupakan produk pendidikan, yakni manusia yang terdidik sesuai standar ideal. Berdasarkan kriteria ekstrinsik, pendidikan merupakan instrumen untuk mendidik tenaga kerja terlatih. Dalam artian deskriptif, mutu ditentukan berdasarkan keadaan senyatanya, misalkan hasil tes prestasi siswa.

Menurut Priansa \& Somad, dalam (Krisbiyanto, 2019) Upaya peningkatan mutu dalam bidang pendidikan difokuskan kepada mutu proses pendidikan. Inti dari proses pendidikan adalah pembelajaran peserta didik di sekolah. Proses pembelajaran yang bermutu melibatkan berbagai input pembelajaran seperti peserta didik, bahan belajar, sarana sekolah, dukungan administrasi, saran prasarana dan sumber daya lainnya serta penciptaan suasana yang konduksif.

Mutu proses pembelajaran ditentukan melalui metode, masukan, suasana, dan kemampuan melaksanakan manajemen proses pembelajaran itu sendiri. Mutu proses pembelajaran akan ditentukan dengan seberapa besar kemampuan memberdayakan sumber daya yang ada untuk peserta didik belajar secara produktif. Manajemen sekolah dan dukungan kelas berfungsi mensingkronkan berbagai input tersebut atau mensinergikan semua komponen dalam interaksi (proses) belajar mengajar, baik antara guru, peserta didik, dan sarana pendukung di kelas baik konteks kurikuler maupun ektra kurikuler, baik dalam subtansi yang akademis maupun yang non akademis dalam suasana yang mendukung proses pembelajaran.

Mutu dalam konteks hasil belajar mengacu pada prestasi yang dicapai oleh sekolah pada setiap kurun waktu tertentu. Prestasi yang dicapai atau hasil pembelajaran dapat berupa hasil tes kemampuan akademis dapat pula prestasi dibidang lain, seperti prestasi disuatu cabang olahraga, seni, atau keterampilan tambahan tertentu seperti komputer atau teknologi, jasa, dan sebagainya. Bahkan prestasi sekolah dapat berupa kondisi yang diukur dengan angka seperti suasana disiplin, keakraban, saling menghormati dan kebersihan. Sesungguhnya antara proses dan hasil pembelajaran yang bermutu dan saling berhubungan, akan tetapi agar proses yang baik tidak salah arah, maka mutu dalam artian hasil harus dirumuskan lebih dahulu oleh sekolah, dan harus jelas terget yang akan dicapainya

\section{HASIL DAN PEMBAHASAN}

\section{Strategi Kepala Sekolah dalam Mengembangkan Sarana Prasarana}

Kepala sekolah merupakan pemimpin yang mengarahkan seluruh kegiatan anggotanya untuk mencapai tujuan sekolah. kepemimpinan dijumpai fungsi pemimpin, pengikut, anggota dan situasi. Kepemimpinan merupakan hubungan dimana satu orang yakni pemimpin mempengaruhi pihak lain untuk dapat bekerja sama dalam upaya pencapaian tujuan (Danim, 2009). Kepala sekolah sebagai seorang pemimpin juga harus memiliki strategi yang tepat agar dapat meningkatkan kualitas pembelajaran, baik dilihat dari segi sarana prasarana dan lain sebagainya. Untuk meningkatkan kualitas pembelajaran dilihat dari segi sarana prasarana, strategi yang dilakukan kepala sekolah adalah sebagai berikut:

\section{Perencanaan sarana prasarana}

Perencanaan merupakan perencanaan meliputi aktivitas pengambilan keputusan mengenai sasaran yang akan dicapai, tindakan yang apa yang akan diambil dalam rangka pencapaian tujuan dan siapa yang akan melaksanakan tugas-tugasnya (Ibrahim, 2008). Perencanaan sarana prasarana yang dilakukan oleh bapak kepala sekolah SMA negeri 1 Jombang adalah yaitu melalui sebuah musyawarah bersama baik dari wakil sarana prasarana, tata usaha sarana prasarana, semua guru, serta orang tua wali murid demi kemajuan sekolah tersebut, mempunyai program dalam satu tahun, merencanakan bagaimana yang dibutuhkan di sekolah untuk mencapai tujuan yang di tetapkan dengan memperhatikan skala prioritas yang dibutuhkan. Perencanaan yang baik disusun 
oleh kepala sekolah tentunya secara tidak langsung akan lebih membantu berjalannya program sarana prasarana yang telah ditetapkan, agar program tersebut berjalan secara efektif dan efisien.

\section{Pengorganisasian sarana prasarana}

Pengorganisasian adalah pengorganisasian yang meliputi pengelompokan orang-orang atau organisasi yang digerakan dalam rangka mencapai kualitas pembelajaran yang di harapkan (Baharuddin, 2010). Pengorganisasian sarana prasarana yang dilakukan oleh bapak kepala sekolah SMA Negeri 1 Jombang dengan melalui struktur organisasi sekolah, yaitu melalui tim seperti wakil sarana prasarana, tata usaha sarana prasarana, pembantu-pembantu pelaksana kegiatan, tim monitoring, perancang dan staf tenaga pendidikan. Pengorganisasian sarana prsarana di SMA Negeri 1 Jombang dilakukan agar dapat mengetahui sarana prasarana yang dikembangkan, ditambahkan serta dikurangi. Hal ini dibuktikan agar dapat menunjang kelengkapan sarana prasarana, sehingga memudahkan siswa siswi dalam proses belajar mengajar agar tercapai tujuan yang telah di tetapkan secara efektif dan efisien.

\section{Penggerakan sarana prasarana}

Selain dari perencanaan dan pengorganisasian sarana prasarana. Penggerakan bertujuan agar semua anggota kelompok berusaha untuk mencapai sasaran sesuai perencanaan yang telah ditetapkan (Baharuddin, 2010). Kepala sekolah SMA Negeri 1 jombang juga melakukan penggerakan sarana prasarana. Penggerakan sarana prasarana dilakukan dengan memanfaatkan tenaga kerja untuk mempergunakan sarana prasarana yang ada, sehingga dari sarana prasarana tersebut guru dapat menjalankan tugasnya sesuai dengan apa yang dibutuhkan.

\section{Pengawasan sarana prasarana}

Pengawasan meliputi usaha yang di tempuh pimpinan dalam membantu personil sekolah demi keberhasilan proses pembelajaran (Sulistyorini, 2009). Pengawasan sarana prasarana yang dilakukan di SMA Negeri 1 Jombang dengan tanggung jawab bersama untuk menjaga, memelihara sarana prasarana yang tersedia sehingga sarana prasrana tersebut dapat bermanfaat sesuai yang telah disediakan.

\section{Peningkatan Kualitas Pembelajaran melalui Sarana Prasarana}

Keberhasilan pembelajaran di sekolah pasti didukung dengan adanya pendayagunaan sarana prasarana pendidikan yang secara efektif dan efisien. Dalam meningkatkan kualitas pembelajaran yang dilakukan oleh bapak kepala sekolah SMA Negeri 1 jombang adalah harus mengetahui kualitas guru karena guru merupakan salah satu kunci keberhasilan pembelajaran.

Guru merupakan faktor utama yang menentukan berhasilnya proses pembelajaran, namun aktivitas guru juga tidak terlepas dari pengawasan kepala sekolah. Pengawasan kepala sekolah juga dilakukan melalui sarana CCTV dan LCD, dengan sarana CCTV dapat membantu untuk meningkatkan proses pembelajaran, dengan CCTV juga bapak kepala sekolah dapat mengawasi bapak ibu guru, dan siswa siswi saat berlangsungnya pembelajaran. Sehingga jika ada yang kurang dan tidak sesuai saat pembelajaran, maka bapak kepala sekolah dapat mengetahui dan menegur bapak ibu guru agar tidak terjadi kesalahan yang sama kembali selain itu juga dapat mealtih kejujuran siswa siswi seperti saat melangsungkan proses ujian. Sedangkan dengan adanya LCD yakni dapat membantu guru untuk memudahkan siswa siswi dalam memahamkan materi-materi yang disampaikan.

Faktor Pendukung Dan Penghambat Kepala Sekolah Dalam Mengembangkan Sarana Prasarana Untuk Meningkatkan Kualitas Pembelajaran. Dalam mengembangkan sarana prasarana terdapat factor pendukung dan penghambat. Faktor Pendukung sarana (CCTV dan LCD). CCTV: dapat memudahkan kepala sekolah untuk mengontrol aktivitas guru ketika berlangsung proses pembelajaran, mendisiplinkan guru agar tepat waktu pada saat masuk ke kelas, melatih kejujuran siswa-siswi sehingga siswa siswi mengurangi pelanggaran dalam kelas dan terkuranginya 
pelanggaran-pelanggaran karena tidak taatnya terhadap peraturan-peraturan. Sedangkan LCD dapat memudahkan untuk memahami pelajaran yang disampaikan oleh bapak ibu guru, penyampaian pesan jadi lebih jelas, guru dapat menvisualisasikan materi dengan jelas serta menumbuhkan sikap proaktif siswa dalam belajar. Adapun faktor penghambat sarana (CCTV dan LCD) yaitu : CCTV dan LCD menggunakan listrik jika listriknya padam maka sulit untuk memantau serta menggunakan LCD saat pembelajaran berlangsung. Strategi kepala sekolah dalam meningkatkan kualitas pembelajaran melalui pengembangan sarana prasarana sudah terprogram secara efektif dan efisien dan sangat membantu dalam meningkatkan kualitas pembelajaran di sekolah tersebut.

\section{KESIMPULAN}

The conclusion consists of a summary of the article that presents a summary of the results of research that has been carried out and is the answer to the formulation of the problem. Conclusions must be aligned with the formulation of the problem and research objectives. If the conclusion is more than one, then it's written using numbering numbers in paragraphs, not by using bullets, and the writer can also add the prospect of development of the results of the research or study as well as how to further implications will be the prospects of research or further research.

\section{REFERENSI}

Amirudin, A. (2019). Model Manajemen Pondok Pesantren dalam Peningkatan Mutu Santri Bertaraf Internasional: Studi pada Pondok Pesantren Amanatul Ummah Mojokerto Jawa Timur. Al-Idarab: Jurnal Kependidikan Islam, 9(2), 222-241. https://doi.org/10.24042/alidarah.v9i2.5607

Ariyanti, N. S., Supriyanto, A., \& Timan, A. (2019). Kontribusi Kepala Sekolah Berdasarkan Ketidaksesuain Kualifikasi Guru Untuk Meningkatkan Kualitas Sekolah. Nidhomul Haq: Jurnal Manajemen Pendidikan Islam, 4(2), 157-168. https://doi.org/10.31538/ndh.v4i2.314

Asmendri. (2014). The Roles of School Principal in the Implementation of Character Education at Boarding School. Al-Ta Lim Journal, 21(2), 104-111. https://doi.org/10.15548/jt.v21i2.87

Badriah, L., Pratiwi, E. S., \& Yusuf, M. (2020). Strengthening Character Education through the Implementation of Madrasah's Culture: A Study at State Islamic Primary School 1 Bantul. Tarbawi: Jurnal Keilmuan Manajemen Pendidikan, 6(01), 37-48. https://doi.org/10.32678/tarbawi.v6i01.2207

Baharuddin. (2010). Manajemen pendidikan islam (1st ed.). UIN-Maliki Press.

Barmawi, \& Arifin, M. (2016). Strategi dan kebijakan pembelajaran pendidikan karakter | Perpustakaan Universitas Sanata Dharma. Ar-Ruz Media. http://library.usd.ac.id/web/index.php?pilih=search\&p=1\&q=0000137573\&go=Detail

Brooks, M. C., \& Sungtong, E. (2016). 'We still have bombings': School principals and insurgent violence in Southern Thailand. International Journal of Leadership in Education, 19(5), 505533. https://doi.org/10.1080/13603124.2015.1059489

Creswell, J. W. (2007). Qualitative inquiry \& research design: Choosing among five approaches (2nd ed). Sage Publications.

Danim, S. (2009). Manajemen dan kepemimpinan transformasional kekepalasekolahan: Visi dan strategi sukses era teknologi, situasi krisis, dan internasionalisasi pendidikan. Rineka Cipta. 
Fajriana, A. W., \& Aliyah, M. A. (2019). Tantangan Guru dalam Meningkatan Mutu Pendidikan Agama Islam Di Era Melenial. Nað̧hruna: Jurnal Pendidikan Islam, 2(2), 246-265. https://doi.org/10.31538/nzh.v2i2.324

Fatoni, M. (2017). Peran Kepala Madrasah Dalam Meningkatkan Mutu Guru Di Mts Nurul Falah Talok Kresek Kabupaten Tangerang. Tarbawi: Jurnal Keilmuan Manajemen Pendidikan, 3(02), 168-182. https://doi.org/10.32678/tarbawi.v3i02.1787

Fauzi, A. (2017). Kepemimpinan Kepala Madrasah Dalam Mengembangkan Lembaga Pendidikan Islam. Nidhomul Haq: Jurnal Manajemen Pendidikan Islam, 2(2), 42-53. http://ejournal.ikhac.ac.id/index.php/nidhomulhaq/article/view/31

Fitrah, M. (2017). Peran Kepala Sekolah Dalam Meningkatkan Mutu Pendidikan. Jurnal Penjaminan Mutu, 3(1), 31-42. https://doi.org/10.25078/jpm.v3i1.90

Fitriani, M. I., \& Hakim, M. V. F. (2021). Principal Leadership Patterns in Collaborating With School Committee. Nidhomul Haq: Jurnal Manajemen Pendidikan Islam, 6(1), 194-205. https://doi.org/10.31538/ndh.v6i1.1384

Hamdi, A. (2019). Manajemen Mutu Program Diniyah Pada Pondok Pesantren MuhammadIyah Lamongan. Nidhomul Haq: Jurnal Manajemen Pendidikan Islam, 4(2), 247-258. https://doi.org/10.31538/ndh.v4i2.463

Ibrahim, B. (2008). Manajemen Peningkatan Mutu Berbasis Sekolah. Kerjasama FIP UM dan DitjenDikdasmen.

Khoiri, N. (2016). Madrasah culture based transformational leadership model. Nadwa: Jurnal Pendidikan Islam, 10, 151-174. http://journal.walisongo.ac.id/index.php/nadwa

Krisbiyanto, A. (2019). Efektifitas Kepemimpinan Kepala Madrasah terhadap Mutu Pendidikan MTsN 2 Mojokerto. Nidhomul Haq: Jumal Manajemen Pendidikan Islam, 4(1), 52-69. https://doi.org/10.31538/ndh.v4i1.182

Lexy J, M. (2011). Metodologi penelitian Kualitatif (29th ed.). Rosdakarya.

Liu, W., \& Gumah, B. (2020). Leadership style and self-efficacy: The influences of feedback. Journal of Psychology in Africa, 30(4), 289-294. https://doi.org/10.1080/14330237.2020.1777033

Lussier, R. N., \& Achua, C. F. (2013). Leadership: Theory, application \& skill development (5th ed). South-Western Cengage Learning.

Ma`arif, M. A., \& Rusydi, I. (2020). IMPLEMENTASI PENDIDIKAN HOLISTIK DI PONDOK PESANTREN AMANATUL UMMAH MOJOKERTO. EDUKASI: Jurnal Penelitian Pendidikan Agama Dan Keagamaan, 18(1), Article 1. https://doi.org/10.32729/edukasi.v18i1.598

Martin, \& Fuad, N. (2016). Manajemen Sarana Dan Prasarana Pendididkan:konsep Dan Aplikasinya/Sm-17. PT RajaGrafindo PErsada.

Miles, M. B., Huberman, A. M., \& Saldaña, J. (2014). Qualitative data analysis: A methods sourcebook (Third edition). SAGE Publications, Inc.

Mulyasa, E. (2013). Pengembangan dan implementasi kurikulum 2013 (Cetakan pertama). PT Remaja Rosdakarya.

Muslimin, T. A., \& Kartiko, A. (2020). Pengaruh Sarana dan Prasarana Terhadap Mutu Pendidikan di Madrasah Bertaraf Internasional Nurul Ummah Pacet Mojokerto. Munaddhomah: Jurnal Manajemen Pendidikan Islam, 1(2), 75-87. https://pasca.jurnalikhac.ac.id/index.php/munaddhomah/article/view/30 
Nilda, N., Hifza, H., \& Ubabuddin, U. (2020). Peran Kepala Sekolah Sebagai Supervisor dalam Meningkatkan Kinerja Guru Pendidikan Agama Islam Sekolah Dasar. Attadrib: Jurnal Pendidikan Guru Madrasah Ibtidaiyah, 3(1), 12-18. https://jurnal.staidagresik.ac.id/index.php/attadrib/article/view/160

Sugiyono. (2014). Metode penelitian Kuantitatif Kualitatif dan R $\approx D$ (Ed. 14). Alfabeta.

Sulistyorini. (2009). Evaluasi Pendidikan dalam Meningkatkan Mutu Pendidikan. Teras.

Tanjong, P. (2017). Strategi Kepala Sekolah dalam Peningkatan Mutu Pembelajaran di SMAN 1 Samalanga Bireun [Skripsi, UIN Ar-Raniry Banda Aceh]. http:/ /ibrary.ar-raniry.ac.id

Wahjosumidjo. (1999). Kepemimpinan kepala sekolab: Tinjauan teoritik dan permasalahannya. Rajagrafindo Persada (Rajawali Pers).

Yuliana, A. T. R. D. (2018). Total Quality Educational Mindset Formation at Muhammadiyah Elementary School Kleco Yogyakarta. Tadris: Jurnal Keguruan Dan Ilmu Tarbiyah, 3(1), 6776. https://doi.org/10.24042/tadris.v3i1.2391 